\title{
Representations of the 'Absent Mother' in Australian Adolescent Fiction
}

\author{
Diana Beere
}

$\mathrm{T}$ This paper is based on a study of representations of 'mothers' and 'motherhood' in the eighteen texts short-listed for the Book of the Year: Older Readers award by the Children's Book Council of Australia (CBCA) in the years 1992 to 1994 . While the CBCA's short list system and the lists themselves are regularly topics of intense debate (Bensemann 1993; Connor 1990; Hanzl 1993), this study focuses on neither the subject matter nor the literary qualities of short-listed books. It is intriguing, nevertheless, that 'literary merit' is explicitly given, but never defined, as the major criterion on which entries for the awards are judged (CBCA 1993), thus leaving open the possibility of the application of more implicit criteria. Given that a significant function of narratives for children and adolescents is the socialisation of their readers into culturally accepted ways of being (Bradford 1996; Stephens 1992), it would not be surprising if any implicit criteria for selecting the 'best' books for young Australians were linked to the ideologies that inevitably pervade them.

Of specific interest here are the ways in which ongoing struggles over competing ideologies of motherhood are played out in recent, critically acclaimed Australian adolescent fiction, just as they are in everyday social and language practices. Like other struggles over social justice issues, these are ideological struggles because they are ultimately contests over interests and the distribution of 'social goods' (cf. Gee 1990) - in this case, over the availability of possible female identities and of opportunities to pursue the interests linked to those identities.

Representations of 'mothers' and 'motherhood' in cultural texts, including fictional narratives produced for adolescents, play a crucial role in these ideological struggles, because they are not simply more or less accurate portrayals of a reality that is independent of them. Representations work to construct reality and experience; in presenting people with possible identities and/or by attributing identity to them, they can impact significantly on human lives (Alcoff 1991-92; Calhoun 1995; Stephens 1996).

Previous studies of books that have won, or been shortlisted for the CBCA's awards (Reeder 1981; Tyquin
1992) have not focused specifically on 'mothers' or 'motherhood', but have found gender stereotyping to be a continuing cause for concern. A review of other relevant research indicates that, in the fictional narratives made available to Australian children and adolescents throughout this century, 'motherhood' has typically been represented in limited and highly conventional terms as virtually synonymous with 'womanhood', and as the expression of supposedly natural feminine capacities to love and nurture. Most commonly, the fictional mother figure has been a white, heterosexual full-time domestic labourer who is selflessly devoted to the care of others, and holds her middle-class, two-parent nuclear family together in times of crisis. Alternatively, she has been a character whose differences from this idealised model of the mother have served more to reinforce its desirability than to challenge it (Anderson \& Yip 1987; Gilbert \& Taylor 1991; Hazell 1989; Lees \& Senyard 1985; Minchinton 1994; Niall 1984; Pearce 1991; Rutherford 1993; Scutter 1993; Tunstall 1992; Welch 1994).

Typical of the latter case is the 'absent mother', various permutations of which — the 'dead mother', the 'invalid mother' - have long been a feature of children's fiction, consistent with the convention of removing adult characters to maximise child protagonists' opportunities for fun and adventures (Lees \& Macintyre 1993; Scutter 1993, 1996). Recently, however, the 'absent mother' has been represented in ways that are increasingly negative (Scutter 1993, 1996). These representations often work to maintain what currently prevail as 'common sense' ideologies of motherhood, by supporting taken-forgranted beliefs that mothers are more responsible than fathers for their children's healthy development across a range of dimensions, and that problems in children's lives are attributable to deficiencies in their mothers (Caplan 1989; Chodorow \& Contratto 1982; Phoenix, Woollett \& Lloyd 1991; Walkerdine \& Lucey 1989; Thurer 1994). Implicit in such beliefs is the assumption that 'good' mothers are full-time carers with no interests beyond the domestic sphere; they are assumed to neither have nor want any separate identities because, as women, they are 'instinctively' inclined to nurture and to take pleasure in merging their own interests with those of their children. 
Such ideas may seem to have little relationship to the realities of child care and parenting in contemporary western society; indeed, everyday experiences and practices constantly challenge them and demonstrate their fundamental impossibility. They have remarkable resilience and power nonetheless. As a cultural ideal, the 'good' mother provides a normative model against which, potentially, all women can be judged by others and by themselves as deficient (Brannen \& Moss 1991). The 'absent mother', for example, is clearly problematic from this perspective, and is always vulnerable to condemnation, regardless of the reasons for, or the duration of, her absence(s). To the extent that representations of the 'absent mother' in recent fiction for children and adolescents work to support such ideologies, they also work to limit the range of legitimate identities available to women and girls, and hence to undermine the achievements of contemporary feminist movements.

In the remainder of this paper, this argument is illustrated with an analysis of the ways in which the 'absent mother' is represented in two texts short-listed for CBCA awards. The first, Galax-Arena (Rubinstein 1992), was an Honour Book in the Older Readers category in 1993; the second, 'Andrew', is included in the collection Love Me, Love Me Nor (Gleeson 1993), which was short-listed in the same category in 1994.

\section{The case of Galax-Arena}

Golax-Arena tells of three Australian children - 13 year old Joella, her older brother Peter, and their younger sister Liane - who are kidnapped for use in scientific research. They are tricked into believing they have been transported to Vexak, a planet beyond the solar system, on which they could not survive were it not for an elaborately simulated Earth-like environment. In fact they have not left Australia; but, convinced that resistance is futile, they abandon all hope of retuming home and accept that their fate is to join a number of other children who have been similarly kidnapped, in most cases apparently from countries in Asia, South America and Africa. These children, the 'peb', perform like circus animals in the Galax-Arena, for what they take to be Vexak's inhabitants. Their future is bleak. Many will die attempting ever more dangerous gymnastic feats for the
'Vexa'; altematively, when they are too old or their performances are too boring or if, like Joella, they have no gymnastic talent, they are 'put to sleep', used for experiments, or kept as pets.

The retrospective narrator is Joella, whose insistence on the importance of telling the truth no matter what the cost, her claimed ability to perceive the truth when others perhaps cannot, and her representation of most of the other characters as shallow and self-interested, all work together to convince readers of her reliability as a narrator. Readers are invited - indeed, virtually obliged - to align their subjectivity with Joella's and to accept the accuracy of her interpretations of events, in order to discover what they otherwise might not, namely 'the truth'. In doing so, they render themselves vulnerable to the effects of the motif of the 'absent mother', which works at the level of the plot and also as a metaphor, and is crucial to the novel's impact as a powerful critique of contemporary social values. To illustrate this, it is first necessary to consider how the three Australian children came to be abducted.

\section{The literally absent mother}

With the exception of Joella, the child characters of the novel all have outstanding gymnastic talents that attracted the attention of their kidnappers. Just as important, however, is the fact that they have no families to miss them and report their disappearances. While this may be disturbing, in most cases it is unlikely to surprise Australian readers familiar with mass media images of homeless children in poverty-stricken 'Third World' countries. However, such meaning-making resources are less helpful for explaining how three children from a white, middleclass family in comfortably affluent Australia could disappear without anyone noticing or caring, and readers are obliged to seek alternative explanations for these children's apparent lack of a 'proper' home and family.

Joella explains that they were travelling to stay at their Aunt Jill's farm, and that 'people on journeys are easy to make disappear' (p.3). However, there is more to the children's vulnerability than this, as Joella has aiready indicated in her description of a family life that had been in many ways typically suburban, until 'Sylvie, our 
mother, decided it was stifling her and she needed what she called time out. We were supposed to stay on in the house with Hayden, but he went very strange after she left' (p.3)

Joella's subsequent descriptions of family life after Sylvie's departure work together to suggest that, here, 'very strange' means 'negligent and irresponsible'. It is their disordered family life that makes it possible for Hythe, a kidnapper who has evidently studied his prey, to intercept the children, having rung Aunt Jill with a story that relies for its plausibility on her familiarity with their parents' 'fecklessness and unreliability' (p.8). Readers can hardly fail to share Joella's view of Peter, Liane and herself as victims of not only their kidnapper, but also their parents' neglect:

I was angry and miserable too, fed up with our parents for making such a mess of our lives, grieving for our animals that we'd had to find other homes for since Hayden would never remember to feed them.

(p.4)

Explicitly, blame for the children's predicament is levelled at both parents; indeed, if there is any imbalance, it is Hayden who is targeted for the most overt criticism. Implicitly, however, readers are positioned to apportion blame quite differently.

Despite her observation that Sylvie has always been 'too young and too crazy to act like an average mother' (p.3), while Hayden was always 'too old and too clever to be a typical dad' (p.3), Joella does not criticise the parenting the children received before Sylvie left; and, significantly, it is to this period of their lives that she returns in her fantasies, dreaming 'of a sunny day in the garden at home. Sylvie was weeding the herb bed and she tumed to speak to me just as 1 woke up. 1 was amazed and delighted: she had come home and we were back in our old house again' (pp.67-68).

In Joella's fantasies, Sylvie is idealised; her return would restore all that the children have lost and heal all their wounds. At the same time, however, Sylvie also becomes the object of blame; as the woman who deliberately left her own children, she represents all that must be repressed in order to keep the fantasy of the perfect mother intact. Joella's observation that it was 'when Sylvie had left [that] Hayden had gone round the twist' (p.16; emphasis added) implies cause and effect. Thus, while Hayden may not be absolved entirely from blame, he can be read as suffering, like his children, as a result of Sylvie's departure, and his inadequacies as a parent can legitimately be excused within the terms of common sense ideologies that construct men as inherently incapable of looking after themselves or their children in the absence of their wives. By contrast, according to prevailing common sense, Sylvie's behaviour is more morally reprehensible than Hayden's; it is she who is ultimately responsible both for her children's neglect by their father, and for their abduction and subsequent suffering at the hands of their kidnappers. The focalisation of the narrative through Joella, and the availability of these ideologies as meaningmaking resources, together invite readers to interpret Sylvie's actions in leaving her family as those of a selfish woman, concerned only with her own interests, and careless of the interests of her husband and children.

Thus it is crucial to the plot that Sylvie has left her family, because subsequent events hinge upon the fact that, as Peter observes when he wonders how they will get home, 'We don't have a home to go to, do we' (p.15). It might be argued that this is merely an example of what has long been a standard narrative device in children's fiction the removal of the adults so that the child characters can have adventures - but adults have not always been removed so viciously (cf. Minchinton 1994; Scutter 1996). Moreover, criticism of the 'absent mother' is evident in Galax-Arena at the level of metaphor as well.

\section{The metaphorical absent mother}

From the perspective that readers are invited to share with Joella, the world is a place where many children are homeless and starving, where "kids fight away dogs from the garbage so they can eat, where life on the streets is lonely and frightening and dangerous, where children are abused, stolen, murdered and no one ever knows where they have gone. No one misses them (p.38).

These are powerful images that work intertextually with familiar media representations of 'Third World' poverty, 
homelessness and repressive political regimes. Similarly, the arguments used by Hythe to persuade the children to accept their fate rely for their effect on readers' familiarity with contemporary discourses of global environmental disaster:

Your planet's stuffed. You belong to a doomed race ... What's life on Earth anyway? Nasty, brutish and short ... If the Big Bang doesn't get you then the Greenhouse effect will... then there's always AIDS. You don't have to worry about that any more ... You'll never be hungry or cold or unemployed ... You're far better off here.

(pp.20-2l)

Readers are invited to recognise the apparent truth of Hythe's claims, and to accept, as Joella soon does, that the peb might well be better off in the Galax-Arena. To confirm this view, Eduardo, a boy of seven or eight, assures Joella in the 'patwa' language of the peb that he misses nothing of his former life, in which there was 'No mama, no papa. No familia. Nada. Jus me in de ciudad [city]. An no food!' (p.38)

I looked around at the peb gathered in the big room and I knew instinctively that for most of them it was the same. No wonder they never referred to themselves as kids or children, except to insult each other. It was far better for them to be the peb of the Galax-Arena, even though they were exiles and slaves, even though they were used as performing animals, than to be children back on Earth.

(p.39)

The narrative thus presents the argument that on a global scale, children have become the innocent victims of a social order based on selfishness, greed, competition and overly materialistic concerns with science and technology. In the absence of more humanistic concerns for relationships and the welfare of others, contemporary society can be read as a 'bad parent' who does not love and protect children from harm, but abandons and/or abuses them physically and emotionally, at best treating them like pets kept for their owners' amusement and benefit.
Furthermore, readers are invited to perceive that such treatment will produce children with similar values to those of the parent generation. Joella observes that the peb 'wanted to survive, and to survive they would do anything - and discard anyone that got in the way' (p.55), and she does not exempt her own brother and sister, who appear not to care when she is taken away to become a pet. Peter, she remarks, seems 'different, as though he was no longer my brother ... He had acquired the aura of the peb. He had become a survivor' (p.38). Significantly, Joella's description of the peb is equally applicable to the so-called Vexa, who are subsequently revealed to be 'human monster[s]' (p.101), prepared to kidnap, enslave and murder children in the hope of extending their own lives indefinitely. The peb, in other words, have come to emulate the values and behaviour of their captors, to the extent that Peter eventually becomes Hythe's deputy, adopting his manner, gestures and language as he colludes with him in preserving the illusion of Vexak and the Galax-Arena.

Clearly, the subject position that readers are most easily able to take up as they engage with the narrative and align their perspectives with Joella's is that of 'innocent child victim' in a world where contemporary adult society and values are effectively the enemy. Again, however, the explicit attribution of blame to adults in general is not as even-handed as it first appears.

It is significant that the qualities dominating contemporary society, as represented in this narrative, are those that are conventionally associated with masculinity, while those that are absent are conventionally associated with femininity, and particularly with mothers and motherhood. Moreover, as noted earlier, according to common sense ideologies it is mothers, not fathers, who are charged with the major responsibility for protecting their children from the dangers of the world outside the 'safe haven' of the family. From this perspective it follows that if contemporary society is failing its children, it is women who do not fulfil their 'proper' roles as the moral guardians of their homes and families who can be held most accountable. The problems of contemporary children can be understood as the result of women's abandonment of their supposedly natural feminine roles as carers and 
nurturers, and their adoption, instead, of supposedly masculine values and roles in the world beyond the domestic sphere.

Ultimately, then, the novel's metaphorical indictment of contemporary society as a bad parent can be read more specifically as an indictment of women as mothers. Moreover, the force of this indictment is strengthened by the representation of Joella as a model of maternal femininity, in contrast to both Sylvie, her own mother, and Peter, her stereotypically 'masculine' brother.

The (present) mother substitute

Significantly, Joella exempts herself not only from her description of the peb as highly competitive and concerned primarily with their own survival, but also from any claims to being special. In contrast to her own professed ordinariness, she describes Peter as a 'golden person' (p.5) with all the qualities necessary for survival in the competitive world of the Galax-Arena. By the end of the novel, however, it is clear that Joella's ordinary, 'feminine' qualities, which are all the qualities of the culturally idealised mother - sensitivity, intuition, selflessness, concern for others - are to be understood as, ultimately, more valuable and more truly heroic than Peter's conventionally heroic 'masculine' qualities.

Thus, in contrast to her own mother - and all the other mothers of the 'abandoned' children of the Galax-Arena - Joella holds her family together in a situation that threatens it. And while Peter's competitive determination exacerbates their troubles, Joella eventually rescues her family which, as a consequence of her selfless, nurturing care for others, is now enlarged to include four of the peb.

\section{Maternity as absent: the non-mother}

The motif of the 'absent mother' operates in yet another way through the character of Emmeline, the supposedly alien being to whom Joella is allocated as a pet. When Joella's quest for the truth prompts her to challenge her owner, she is revealed as a 119 year old woman who relates the bizarre story of Project Genesis Five and the reason for the dangerous gymnastics. Emmeline admits to having had doubts about the project when she saw that children were being killed, and acknowledges that ' 1 wasn't sure I wanted to live for ever after all' (p.103).
However, she had accepted the researchers' explanations and their offer of a 'little child of my own to look after' (p.103), and tells Joella, 'you made me want to start living again. I had to live to look after you' (p.104). Later, Emmeline confesses, 'I would have liked to have children ... Then I would be leaving something behind' (p.107).

It is significant that the only 'Vexa' character actually represented in the novel is a woman who has had no children. Such women are commonly perceived to be unnatural and selfish, and here the narrative works to reinforce such notions by linking Emmeline's selfish obsession with defying nature with her failure to fulfil her 'natural' role in life by becoming a mother. Readers are invited to perceive that, had she had children of her own, Emmeline would have been less fearful of death.

Joella's narrative ends bleakly: the world is still the same uncaring place, and no hope for change is offered, except in so far as readers are positioned to view the restoration of 'absent mothers' to the domestic sphere as the solution to the problem of neglected and abused children throughout the contemporary social world. In the character of Sylvie, the 'absent mother' is represented as a woman who pursues her own interests outside the family context and thus exposes her children to harm - from which they are rescued by Joella, the model of maternal heroism. At the metaphorical level, contemporary society is characterised by an absence of conventional maternal values; and in the character of Emmeline, the most extreme consequences of maternal absence are linked to a self-centred old woman's failure to become a mother at all. Together, the representations of the 'absent mother' in Galar-Arena work to link the qualities and values supposedly missing from contemporary society with biological femininity, and to construct women who choose not to have children, or to pursue interests and desires outside the domestic sphere, as unnatural social criminals.

\section{The case of 'Andrew' in Love Me, Love Me Not}

A contrasting representation of the 'absent mother' and the effects of her absences is offered in the story of Andrew in Love Me, Love Me Not. Narrated in the third person, the story is focalised entirely through Andrew, whose view of the world - and his mother - readers are 
invited to share. Thus it is crucial to this more positive representation that Andrew himself does not perceive his mother's apparently frequent absences to be a problem. Like the other protagonists in the nine linked short stories, Andrew is negotiating the complexities of peer group relationships as he moves into adolescence. In particular, he is uncertain about how to talk to girls and concemed about honesty in friendships; and, as in Joella's case, his concern with truthfulness reinforces readers' trust in Andrew as a narrator whose interpretations of events can be accepted as reliable. It is sufficient for the purposes of this analysis to observe that Andrew does develop his understanding of the issues that concern him; precisely how he does so, however, is of less interest here than the family context in which he is able to do so.

Of particular interest is the representation of Andrew's mother as a woman whose life is not centred on her children and who, as a consequence, is often absent from the home. Like the other members of the family, she has an identity and interests that are independent of her relationships with her children, but readers are positioned to perceive her pursuit of those interests to be no more reprehensible than her husband's passion for jazz or Andrew's fascination with his fossil collection.

While Andrew is not sure how his friends would react if he confessed that 'music' in his family means jazz and blues, rather than rock and heavy metal, there is no suggestion that either he or his older sister, Anna, feels 'abandoned' when their father 'plays blues in the pub on Friday nights while Mum sings and plays sax' (p.126). Similarly, when his parents and their visitors make an impromptu trip to the pub, leaving him with the visitors' children, Andrew does not perceive this as a problem:

'Andrew?' His mother came towards him. She was pulling a light cardigan around her shoulders. 'We're all going down to the pub to hear the last set. Anna wants to come with us. You'll keep an eye on the little ones, won't you?'

'Yeah.'

They went and Andrew took the kids inside and found an old video to put on for them. He fed them ice-cream and watched the movie with them for a while and then got bored and went off to his room to work with his collections.

(p.127)

Andrew may be bored with the movie and the company of the children but, like his mother, he has his own interests to pursue and feels comfortable about doing so. There is no suggestion that adults in general, or his parents in particular, represent 'the enemy'; nor are readers invited to perceive Andrew as a victim of parental neglect. On the contrary, it is clear that he has a comfortable, mutually supportive relationship with his mother, who takes an interest in his life and gives thoughtful advice when asked, without necessarily making Andrew's concerns her own:

Andrew grinned and gave her his cheek to kiss. He stopped at the door. 'Mum, can I ask you something?'

'Please do. As long as it isn't about fossils. '

'What would you do if a class you were doing was all rubbish? It was just wrong what the teacher was saying?'

His mother poured coffee into a mug and swirled it around. 'I'd think very carefully about it. I'd make sure I knew what I was talking about and then I'd tell the teacher what I thought. Politely. though. 'She looked up at him. 'Do you want to tell me more?'

'No, it's okay.'

(p.129)

Indeed, it is okay. Andrew puts his mother's advice to constructive use at school, and later returns home to find Anna heating soup in the kitchen

'Hi,' she said. 'Mum and Dad have gone to a meeting. I'm going over to Rick's place to study. Mum said to help yourself to some food. 'She sipped the reddish liquid from the spoon. 'As if you need any encouragement. They'll be home about ten.

(p. 133)

Again, there is no suggestion that Andrew feels abandoned or neglected; instead, readers are invited to share his enjoyment of the opportunity to pursue his own concerns 
in the space that is made avaitable by the absence of his family. It is during this time, and as a consequence of having taken his mother's advice regarding his problem at school, that Andrew successfully negotiates what is apparently his first telephone conversation with a girl, and receives an invitation to a party. Afterwards, he goes into the lounge room and looks through his parents' collection of records, tapes and CDs; and, significantly, it is one of his mother's favourites that he chooses:

His mother's fovourite Billie Halliday [sic] album was on top of the cabinet. He took the old vinyl record out of its sleeve and wiped off the dust. He turned the lights down, switched on the record player and watched as the arm lifted across and dropped onto the black circle. The music came, slow and reedy. Clarinet maybe withpiano behind it. Then trumpet and saxophone. Like Mum's, only better. Through the scratches came the high lonely voice. Love and losing. Sadness. Sorrow. Love and gaining again and again.

(p.136)

As the story closes, Andrew is comfortably alone, singing and dancing as he has never done before, and wondering if what he is experiencing is what his mother means when she talks of music that makes 'your flesh crawl and your guts turn over' (p.126). This is not the behaviour of a boy who has a problem with his mother's absences; rather, Andrew's enjoyment of his mother's music suggests that he respects and finds value in her pursuit of a separate identity and separate interests. It must be acknowledged, nonetheless, that even this more positive representation of the 'absent mother' is not without an element of contradiction: notwithstanding her separate identity, Andrew's mother is still 'Andrew's mother', and remains otherwise nameless throughout the story.

\section{Conclusion}

In the two examples of recent, critically acclaimed Australian adolescent fiction discussed here, the ways in which the 'absent mother' is represented have contrasting implications for the (re)production of ideologies of motherhood. In Galax-Arena, the 'absent mother' who pursues her own interests beyond the domestic sphere is represented as inherently problematic - unnatural, selfish, and ultimately responsible for family disintegration and the sufferings of contemporary children on a global scale. The narrative works to reproduce conventional, common sense ideologies of motherhood that conflate the identities of 'woman' and 'mother', and hold mothers accountable for whatever problems their children experience; at the same time, they idealise the 'good' mother as one who displays ordinary 'maternal' heroism by sacrificing her own needs and interests to those of her children, thus rendering herself literally self-less. Such limited conceptions of mothers and motherhood have been challenged in recent decades by feminist campaigns to expand the range of legitimate identities available to women beyond that of 'mother'. In providing support for these ideologies, however, Galax-Arena exemplifies the efforts of contemporary backlash movements that work to undermine the achievements of feminism and restore women to their 'proper' place within the domestic sphere (cf. Faludi 1992; Ireland 1993).

By contrast, in Love Me, Love Me Not, the story of Andrew illustrates that the 'absent mother' need not always be understood as a negative force in the lives of her children. This narrative offers some challenge to prevailing ideologies of motherhood by representing an 'absent mother' whose rights to an identity separate to that of 'mother' - albeit one that is nameless - and rights to pursue interests of her own are never questioned. Instead, they are accepted as no less legitimate than those of other members of her family. Rather than being inherently damaging to them, this mother's assertion of those rights, and her consequent absences from the home, allow her children space in which to grow and develop their own separate identities.

These two examples illustrate some of the ways in which ongoing ideological struggles over social identities and institutions such as 'mother' and 'motherhood' are played out in fictional texts judged to be among the best Australian books published for young people. The preliminary findings of the larger study from which these analyses are drawn indicate that, in recent years, 'backlash' representations of mothers and motherhood, such as those found in Galax-Arena, have been common in books short-listed in the Older Readers category of the CBCA's 
annual children's literature awards. However, the findings also reveal some signs of resistance to prevailing common sense ideologies of motherhood, and of attempts to develop less limited and limiting understandings of what it means to be a mother, as in the story of Andrew in Love Me, Love Me Not.

Two salient questions emerge. First, to what extent is ideological support for conventional, normative versions of motherhood an implicit criterion for judging entries for the CBCA's awards? Second, when social justice is at stake, are vague conceptions of 'literary merit' sufficient criteria for judging the quality of books for young Australians?

\section{References}

Alcoff, L. (199 1-92) 'The problem of speaking for others', Cultural Critique 20, 5-32.

Anderson, J. \& Yip, L. (1987) 'Are sex roles represented fairly in children's books? A content analysis of old and new readers', Unicorn 13, 3, 155-161.

Bensemann, J. (ed) (1993) Children's Book of the Year A wards 1993: Short List Information. Croydon, Vic., Children's Book Council of Australia.

Bradford, C. (1996) 'Centre and edges: Postcolonial literary theory and Australian picture books', in C. Bradford (ed) Writing the Australian Child: Texts and Contexts in Fictions for Children. Nedlands, WA, University of Western Australia Press, pp.92-110.

Brannen, J. \& Moss, P. (1991) Managing Mothers: Dual Earner Households After Maternity Leave. London, Unwin Hyman.

Calhoun, C. (1995) Critical Social Theory: Culture, History and the Challenge of Difference. Oxford, Blackwell.

Caplan, P. (1989) Don't Blame Mother: Mending the Mother-Daughter Relationship. New York, Harper \& Row.

Children's Book Council of Australia (1993) Awards Handbook 1993. Hunters Hill, NSW, Children's Book Council of Australia.

Chodorow, N. \& Contratto, S. (1982) 'The fantasy of the perfect mother', in B. Thome (ed) Rethinking the
Family: Some Feminist Questions. New York, Longman, pp.54-75.

Connor, J. (1990) 'Glittering prizes?', Magpies 5, 4, 10-12.

Faludi, S. (1992) Backlash: The Undeclared War Against Women. London, Vintage.

Gee, J.P. (1990) Social Linguistics and Literacies: Ideology in Discourses. London, The Falmer Press.

Gilbert, P. \& Taylor, S. (1991) Fashioning the Feminine: Girls, Popular Culture and Schooling. Sydney, Allen \& Unwin.

Gleeson, L. (1993) Love Me, Love Me Not. Ringwood, Vic., Penguin.

Hanzl, A. (1993) 'Children's literature in Australian schools: Looking back and looking forward', The Australian Journal of Language and Literacy 16, 85-98.

Hazell, A.M. (1989) Reflections of Reality? Female Roles in Australian Adolescent Fiction Since World War II. Blackwood, SA, Auslib Press.

Ireland, M.S. (1993) Reconceiving Women: Separating Motherhood From Female Identity. New York, The Guilford Press.

Lees, S. \& Macintyre, P. (1993) The Oxford Companion to Australian Children's Literature. Meibourne, Oxford University Press.

Lees, S. \& Senyard, J. (1985) 'Taste and table manners: Class and gender in children's books of the 1950s', The Australian and New Zealand Journal of Sociology 21, 174-193.

Minchinton, B. (1994) 'Gillian Rubinstein and her women', Papers: Explorations into Children's Literature 5, 2 \& 3, 113-124.

Niall, B. (1984) Australia Through the Looking-glass: Children's Fiction 1830-1980. Carlton, Vic., Melbourne University Press.

Pearce, S. (1991) 'Growing up gender-wise: What we give to girls', Magpies 6, 5, 10-14.

Phoenix, A., Woollett, A. \& Lloyd E. (eds) (1991) Motherhood: Meanings, Practices and Ideologies. London, Sage. 
Reeder, S.O. (1981) 'Sex-role stereotyping in Australian Children's Book of the Year Award winners 1950-80', Reading Time 25, 10-16.

Rubinstein, G. (1992) Galax-Arena. Ringwood, Vic., Puffin Books.

Rutherford, L. (1993) “"Lineaments of gratified [parental] desire": Romance and domestication in some recent Australian children's fiction', Papers: Explorations into Children's Literature 4, 1, 3-13.

Scutter, H. (1993, September) 'Keeping Mum'. Paper presented at the 'Body in the Library' Conference, University of Queensland, Brisbane.

Scutter, H. (1996) 'Representing the child: Postmodern versions of Peter Pan', in C. Bradford (ed) Writing the Australian Child: Texts and Contexts in Fictions for Children. Nedlands, WA, University of Western Australia Press, pp.1-16.

Stephens, J. (1992) Language and Ideology in Children's Fiction. New York, Longman.

Stephens, J. (1996) 'Children's literature, interdisciplinarity and cultural studies', in C. Bradford (ed) Writing the Australian Child: Texts and Contexts in Fictions for Children. Nedlands, WA, University of Western Australia Press, pp.161-179.

Thurer, S.L. (1994) The Myths of Motherhood: How Culture Reinvents the Good Mother. Ringwood, Vic., Penguin Books.

Tunstall, G. (1992) The Image of Mothers in Contemporary Children's Picture Books. Kuring-Gai, Sydney, University of Technology Sydney.

Tyquin, J. (1992) 'Is the world full of women too?', Idiom 27, 2, 12-20.

Walkerdine, V. \& Lucey, H. (1989) Democracy in the Kitchen: Regulating Mothers and Socialising Daughters. London, Virago.

Welch, B. (1994) 'Parents now and then', Viewpoint: On Books for Young Adults 2, 4, 8-9.
This article was originally published in Old Neighbours New Visions: Selected Papers from the First Conference of the Australasian Children's Literature Association for Research. ed. Maureen Nimon, Centre for Children's Literature, University of South Australia, 1997.

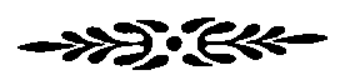

\section{BIOGRAPHICAL NOTE}

Diana Beere is from the Faculty of Education, Griffith University. This paper is drawn from her Ph.D. research.

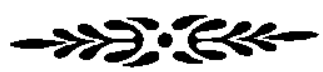

\section{ACKNOWLEDGEMENTS}

Papers 8: 31998 